\title{
Potential Overflow of Mojave Creek near Disposal Site, Edwards Air Force Base, California
}

By RANDAL L. DINEHART and JERRY G. HARMON

U.S. GEOLOGICAL SURVEY

Open-File Report 98-97

Prepared in cooperation with the

U.S. DEPARTMENT OF THE AIR FORCE

N

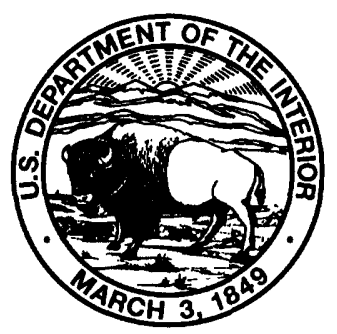




\title{
U.S. DEPARTMENT OF THE INTERIOR BRUCE BABBITT, Secretary
}

\author{
U.S. GEOLOGICAL SURVEY
}

Thomas J. Casadevall, Acting Director

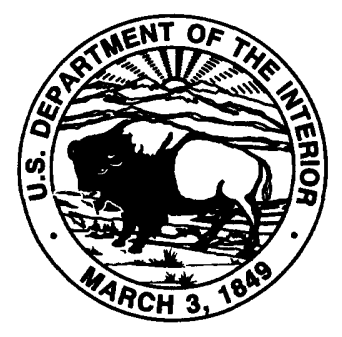

The use of firm, trade, and brand names in this report is for identification purposes only and does not constitute endorsement by the U.S. Geological Survey

For additional information write to:

District Chief

U.S. Geological Survey

Placer Hall, Suite 2012

$6000 \mathrm{~J}$ Street

Sacramento, CA 95819-6129
Copies of this report can be purchased from:

U.S. Geological Survey

Information Services

Box 25286

Federal Center

Denver, CO 80225 


\section{CONTENTS}

Abstract

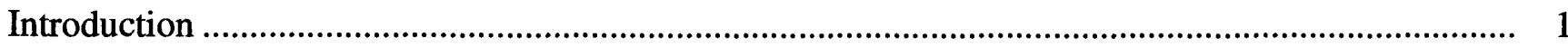

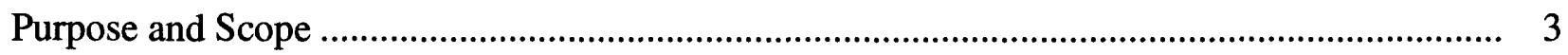

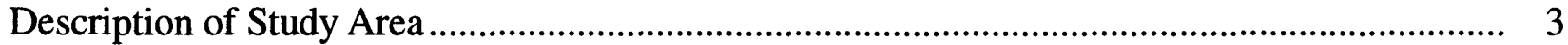

Evidence of Flood Magnitude in Mojave Creek ................................................................................... 3

Sedimentological Evidence ........................................................................................... 5

Hydraulic and Hydrologic Information........................................................................... 7

Flood Discharges from Regional Characteristics ......................................................................... 10

Water-Surface Profiles in Floodplain near Main Base Landfill................................................... 11

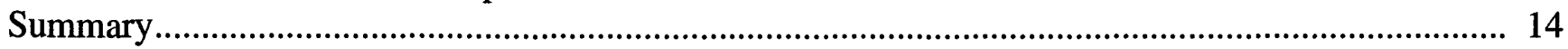

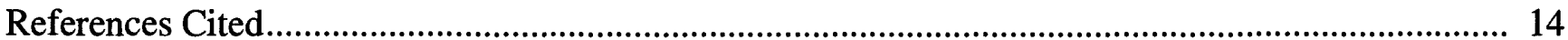

\section{FIGURES}

1. Map showing location of Edwards Air Force Base, California, and Main Base Landfill.

2. Map showing soils and vegetation along the Mojave Creek near the Main Base Landfill,

Edwards Air Force Base

3-7. Photographs showing:

3. Small channel of Mojave Creek near the Main Base Landfill, Edwards Air Force Base

4. Thin layer of cracked mud on the floodplain surface of Mojave Creek near the Main Base Landfill, Edwards Air Force Base

5. Distal end of an alluvial fan at Mojave Creek near the Main Base Landfill intersected by the railroad grade, Edwards Air Force Base

6. Crest-stage gage in a confined channel of Mojave Creek, Edwards Air Force Base 7

7. Wooden culvert through which water passes from south to north under the railroad grade immediately upstream from the flow path across the unpaved Mojave Road, Edwards Air Force Base

8. Map showing floodplain of Mojave Creek near the Main Base Landfill boundary, Edwards Air Force Base

9. Graph showing elevation plots of cross sections of the floodplain for the water-surface profile, Edwards Air Force Base

\section{TABLE}

1. Water-surface elevations computed using standard-step method for Mojave Creek near the Main Base Landfill, Edwards Air Force Base 


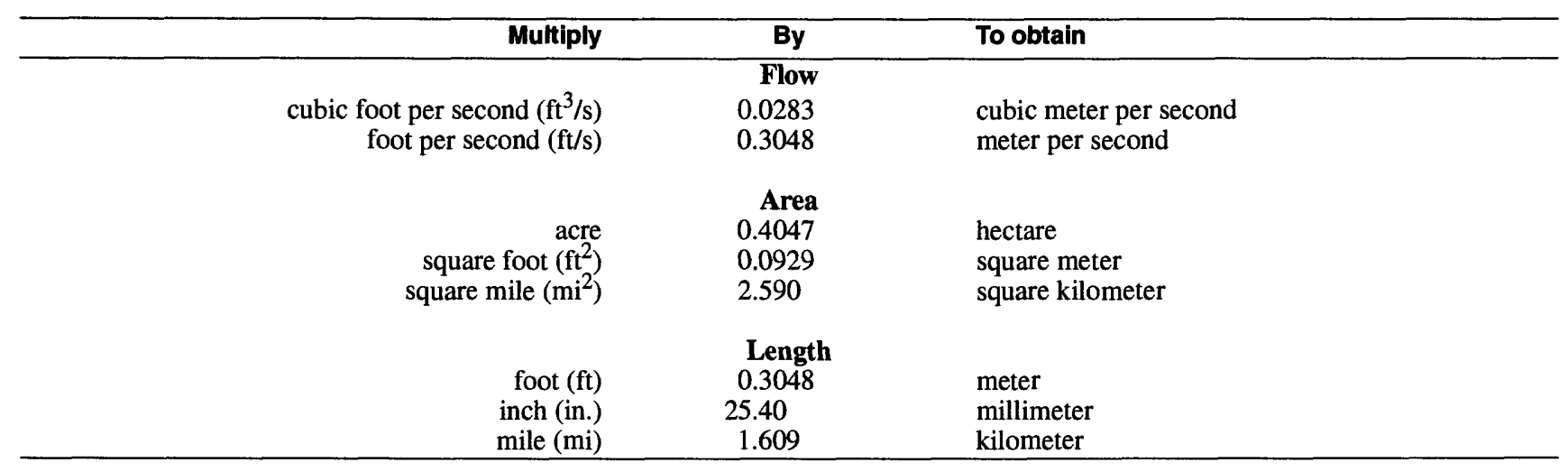

\section{Vertical Datum}

Sea level: In this report, "sea level" refers to the National Geodetic Vertical Datum of 1929-a geodetic datum derived from a general adjustment of the first-order level nets of both the United States and Canada, formerly called Sea Level Datum of 1929. 


\title{
Potential Overflow Of Mojave Creek Near Disposal Site, Edwards Air Force Base, California
}

\author{
By Randal L. Dinehart and Jerry G. Harmon
}

\section{ABSTRACT}

Sedimentological evidence in Mojave Creek near Edwards, California, indicates that the largest discharge in the last hundred years near the disposal site of the Main Base Landfill at Edwards Air Force Base was a few hundred cubic feet per second. The distal ends of two alluvial fans on the Mojave Creek floodplain near the Main Base Landfill have not been eroded substantially since sediment supply was cut off by a railroad grade completed in 1884. Previous estimates of flood discharges were 4,000 cubic feet per second and larger in this reach; the estimates were calculated by regression equations derived from regional characteristics. However, a 100 -year rainfall in 1983 failed to produce erosion in Mojave Creek commensurate with discharges of greater than about 100 cubic feet per second. To test the potential for the creek to overflow and reach the disposal site, a hypothetical discharge was used to determine the depth of flooding at local cross sections. Although the access road from Mojave Boulevard to the Main Base Landfill may be inundated during a flood, the artificial grade at the disposal site would not be reached at a discharge of 2,000 cubic feet per second, which is an order of magnitude greater than the apparent flood discharges that occurred during the past hundred years in Mojave Creek near the present Main Base Landfill.

\section{INTRODUCTION}

The best documentation of floods in a stream valley lies in the discharge records of past floods as measured by hydrographers. Where no discharge records exist, the valley can be examined for sedimentological evidence of flooding. In addition, regression statistics for streams in similar watersheds can be applied to the stream in question. Finally, the hydraulic capacity of the stream can be calculated for a flood discharge related to the local channel conditions.

Mojave Creek is an ephemeral stream near Edwards Air Force Base (AFB), California (fig. 1), with a drainage area of $182 \mathrm{mi}^{2}$ and a poorly defined channel for which no discharge measurements have been made. Managers at Edwards AFB expressed concern to the U.S. Geological Survey (USGS) about the possibility of flooding near the disposal site of the Main Base Landfill above Mojave Creek. Therefore, the potential for overflow of Mojave Creek near the Main Base Landfill was studied, in cooperation with the U.S. Department of the Air Force, primarily by examining sedimentological features and local hydraulic and hydrologic information. The study also included calculation of a water-surface profile for a hypothetical flood discharge.

Waste-discharge requirements set forth by the California Regional Water Quality Board in 1992 (Earth Technology, 1993) for the Main Base Landfill stipulated that

The disposal site shall be adequately protected against inundation and/or washout from a storm or flood having a recurrence interval of once in 100 years... 


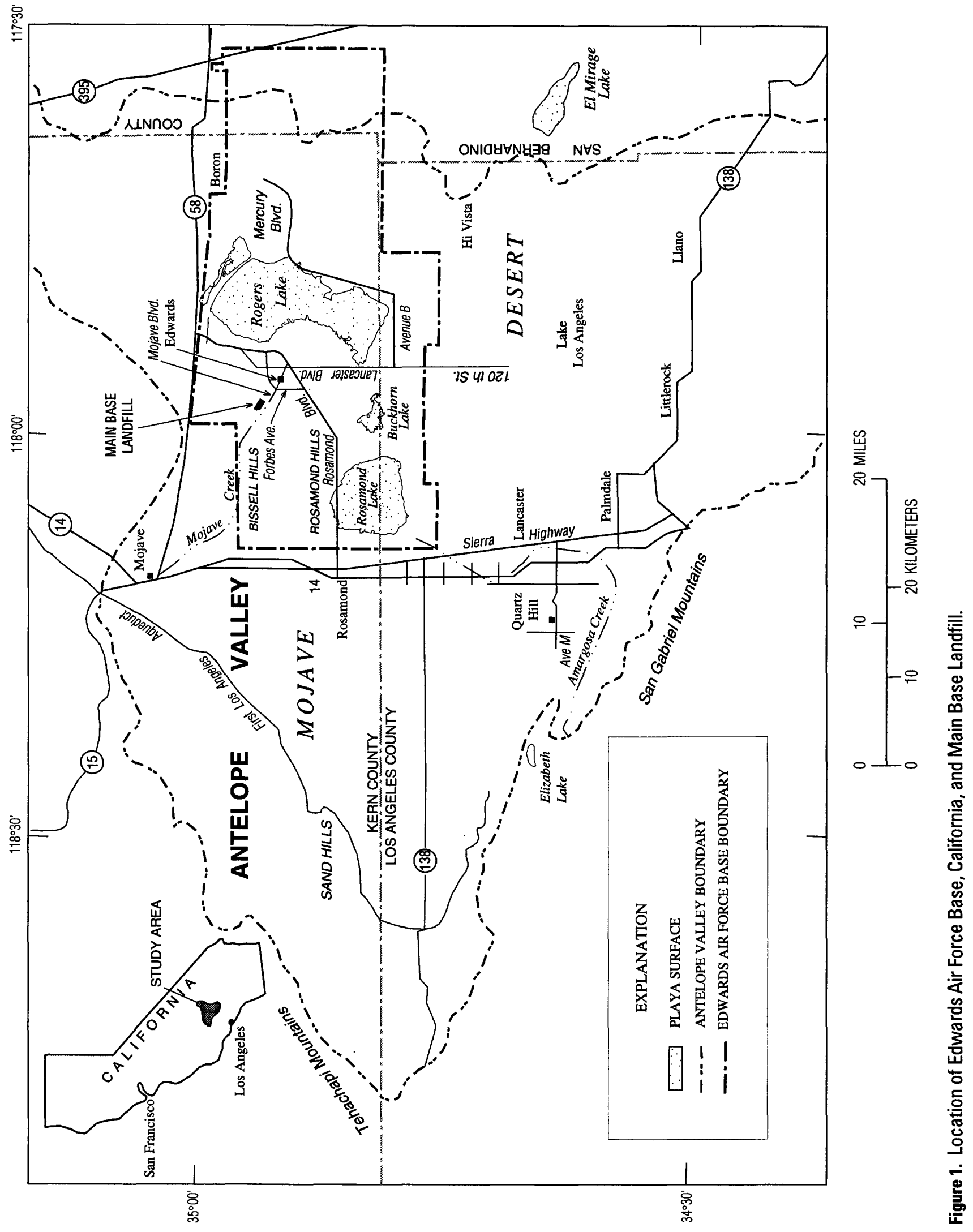


Because the stipulation involved a flood defined by recurrence interval, the potential for overflow was investigated with reference to published flood boundaries drawn for a 100-year flood (GRW Engineers, 1993). The published flood boundaries had been mapped for studies of Mojave Creek near the Main Base using 100-year flood discharges derived from a combination of regional characteristics, statistics, and watershed simulation. A consulting firm (GRW Engineers, 1993) and the U.S. Army Corps of Engineers (GRW Engineers, 1993) both derived flood discharges for Mojave Creek greater than $4,000 \mathrm{ft}^{3} / \mathrm{s}$ at Forbes Avenue near the Main Base Landfill.

\section{Purpose and Scope}

The purpose of this report is to describe the potential for flooding from the Mojave Creek channel to reach the Main Base Landfill northwest of Edwards, California. This study examined sedimentological features to determine flood magnitude at this site. The scope of this report is limited to the presentation of local hydrologic information and the calculation of a water-surface profile for a hypothetical flood discharge in the reach of Mojave Creek near the Main Base Landfill.

\section{Description of Study Area}

Edwards AFB is located in the Antelope Valley of south central California and occupies about $470 \mathrm{mi}^{2}$, with the main military installation at the west side of Rogers Lake (fig. 1). Antelope Valley is bordered on the southwest by the San Gabriel Mountains and on the northwest by the Tehachapi Mountains. The V-shaped mountain border inhibits the passage of moist Pacific Ocean air to the Antelope Valley. Rainfall is sparse and widely scattered in the Antelope Valley. Average annual rainfall at Edwards AFB near Rogers Lake for the years 1942-95 was 5.04 in. (Phillip Harvey, U.S. Air Force, written commun., 1996).

The Main Base Landfill serves Edwards AFB by providing trash compaction for local burial at the disposal site on a low hill above Mojave Creek (fig. 2). The Main Base Landfill has an area of 125 acres surrounded by a fence on a hill to the northeast of Mojave Creek. Borrow pits for the disposal site are located in a separate area $(600 \times 3,000 \mathrm{ft})$ between lines of power poles to the southwest of Mojave Creek. The name
Mojave Creek (known locally as Cache Creek) refers to the ephemeral stream that flows to the town of Edwards, California, from the stream valley north of Bissell Hills (fig. 1). Downstream from the Main Base Landfill, storm runoff flows within a depression along the south side of Mojave Boulevard toward Forbes Avenue. Storm runoff passes through a culvert under Forbes Avenue and continues along a storm-drainage channel on the north side of Mojave Boulevard.

Topographic maps indicate that the drainage basin for Mojave Creek extends from the town of Mojave to Rogers Lake. The drainage area is about 182 $\mathrm{mi}^{2}$, most of which is upstream from Forbes Avenue. At the time of this study (1996), the main development in the watershed upstream from Forbes Avenue was the Main Base Landfill. About $10 \mathrm{mi}^{2}$ of urbanized, sloped land produces storm runoff to Mojave Creek downstream from Forbes Avenue.

Daily rainfall records for Edwards AFB show that the largest rainfall for 24-hour periods between 1942 and 1995 ranged from 1 to 1.5 in. (Phillip Harvey, U.S. Air Force, written commun., 1996). Localized cloudbursts with high rainfall intensity, but smaller totals can occur in summer. Widespread rain occurs most often in the winter months, and is usually associated with the largest rainfall amounts. Even with intense rainfall, hydrologic response of Mojave Creek is slow. The high infiltration capacity of the drainage basin delays the onset of stormflow. Soils beneath the floodplain adjacent to the Main Base Landfill are gravelly sands of decomposed granite. Borehole logs show that alluvial sand of Holocene age near the base of the disposal site extends to a depth of $40 \mathrm{ft}$ (Earth Technology, 1993).

\section{EVIDENCE OF FLOOD MAGNITUDE IN MOJAVE CREEK}

To locate physical evidence of flood magnitude, USGS hydrologists inspected several miles along Mojave Creek during December 1995 and January 1996. This section presents sedimentological evidence observed on the ground and in aerial photographs, followed by hydraulic and hydrologic information gathered in the area. 


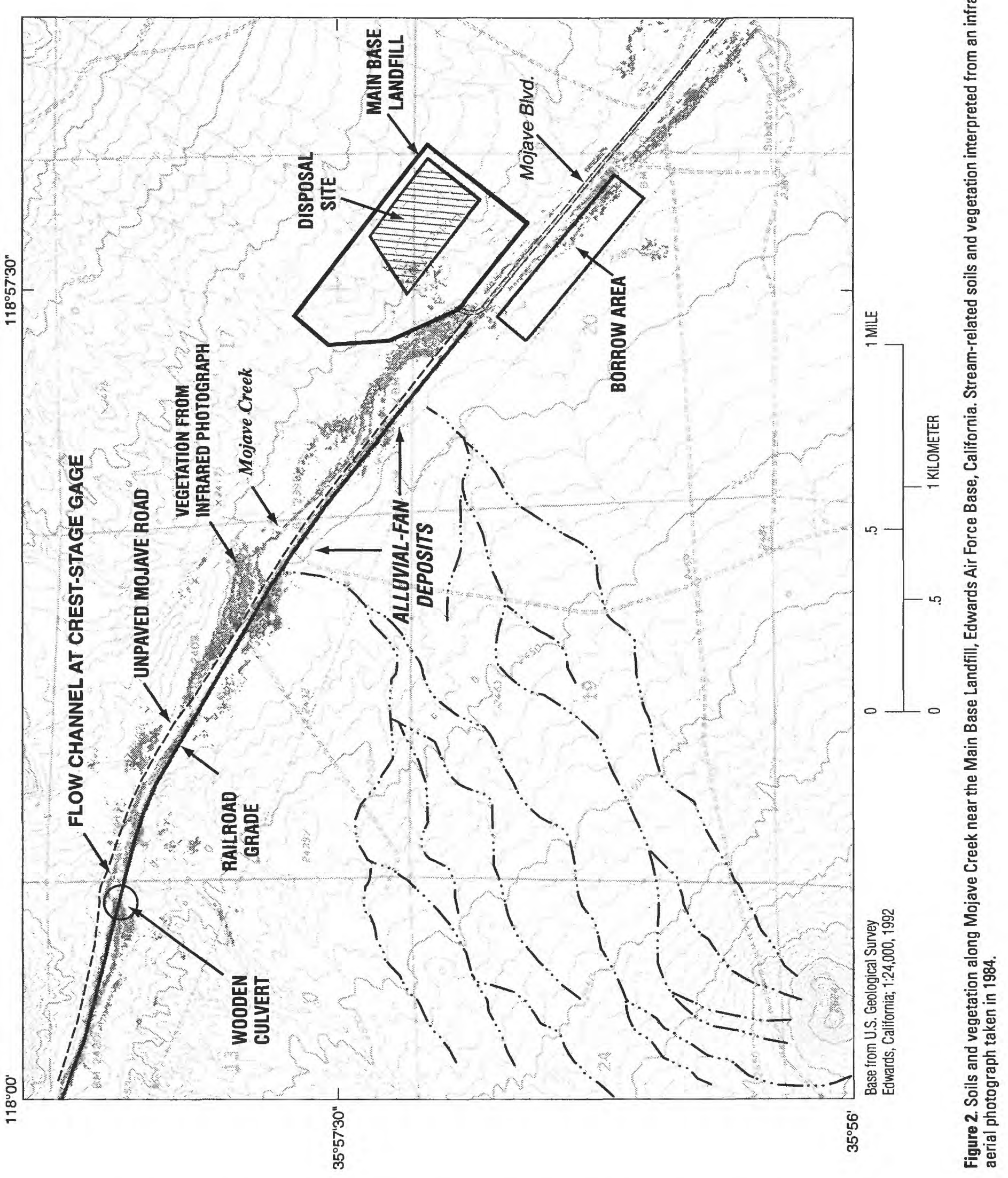




\section{Sedimentological Evidence}

About 0.25 mi upstream from the Main Base Landfill, flow in Mojave Creek has formed several narrow channels that are less than $2 \mathrm{ft}$ in depth (fig. 3 ). Between the channels, intervening areas of the floodplain have a surface of silty sand vegetated with grass and small desert shrubs. The floodplain was inundated during the rainy period of March 1995, as is indicated by the puffy, unmarked texture that is typical of recently dried ponds. A thin layer of cracked mud (fig. 4) extends from the distal end of the alluvial fan to the hill bordering the northeast side of the floodplain.

The present floodplain does not appear to have formed in response to the current hydrologic regime of Mojave Creek. Dutcher and Worts (1963) concluded that the arid watersheds of the Antelope Valley gained their present form more than 10,000 years ago (during the Pleistocene geologic epoch), when rainfall was plentiful; that is, the present stream valley represents flows on surfaces formed in a wetter climate.
Mojave Boulevard is unpaved west of the landfill. The road diverges at the landfill, splitting to the abandoned railroad grade for the Atchison, Topeka, and Santa Fe Railway and to an adjacent, parallel road (unpaved Mojave Road). This study found narrow bands of sedimentation on the unpaved Mojave Road, indicating that local runoff occupies the road before reaching the ephemeral stream channel. At several places, flows have crossed the road into a low area between the road and the railroad grade. A larger view of flow along Mojave Creek was subsequently obtained by examining aerial photographs of the local area.

Patterns of vegetation along Mojave Creek and alluvial-fan deposition at the base of small tributaries to Mojave Creek are visible in aerial photographs taken in September 1984 and August 1985 as part of the Infrared High-Altitude Photograph program of the USGS. The photographs were examined for features relevant to floodflows along Mojave Creek. Infrared photographic film is sensitive to thermal differences caused by living vegetation and denser vegetation registers as darker shades. This property of the film was used to

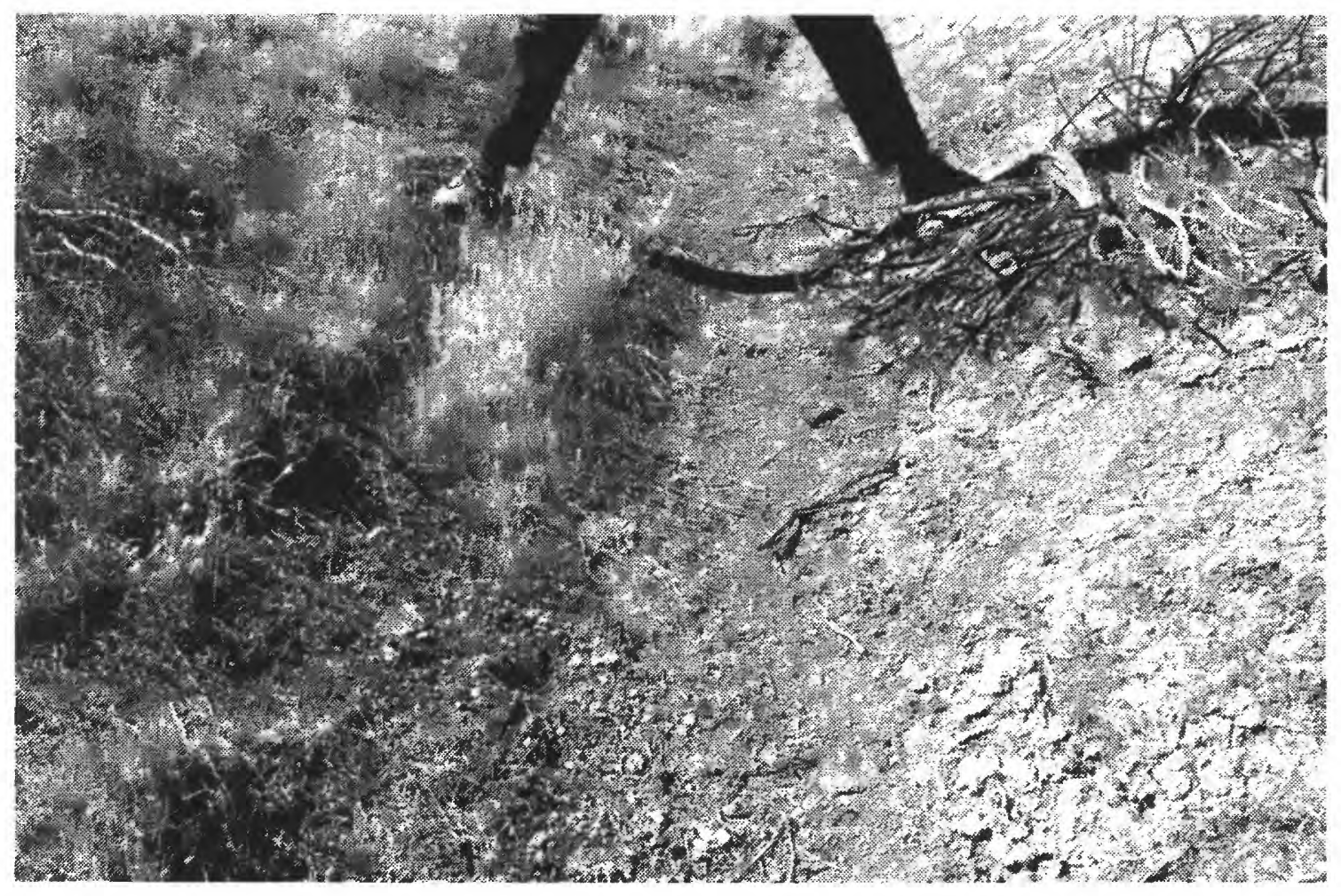

Figure 3. Small channel of Mojave Creek near the Main Base Landfill, Edwards Air Force Base, California. Mojave Creek is an ephemeral stream that has formed several narrow channels with depths less than 2 feet. Flow is toward the foreground. 
digitally enhance the vegetation patterns in a scanned aerial photograph of the Mojave Creek floodplain. The vegetation patterns were transferred to a topographic map (fig. 2). The darkened areas are considered to be the outline of soils wetted by local runoff from tributaries and streamflow along Mojave Creek. Southwest of the Main Base Landfill, the darkened areas form the outline of a meandering stream. The darkened areas on both sides of the unpaved Mojave Road and the railroad grade probably represent vegetation (grasses and/or desert shrubs) that survives on water from recent storms that is trapped in the silty sand of the relict stream outline.

The diagnostic value of one of the infrared photographs is demonstrated at the northwest corner of figure 2, where the main channel is north of the unpaved Mojave Road. Darkened patches appear alternately along both sides of the unpaved Mojave Road farther downstream, indicating probable areas where stormflow crossed the road. The fact that the darkened areas are not continuous on both sides of the road indicates that stormflows have not been large enough to inundate the road entirely.
Two separate drainages trend northeast toward the railroad grade (fig. 2). Both drainages originate at a hill about $440 \mathrm{ft}$ above the floodplain. Although each drainage unites and is intersected by the railroad grade (fig. 5), an alluvial-fan shape is visible in the deflection of the darkened area on the northern side of the railroad grade (fig. 2).

The alluvial-fan deposition of loose sand at the distal ends of these tributaries leads to a useful interpretation of the vegetation pattern. The pattern is visible on both sides of the railroad grade, which was completed in 1884 (Mark Hagan, U.S. Air Force, written commun., 1996). Because the railroad grade has no stream crossings near the Main Base Landfill, no additional sand from the alluvial-fan source has been transported to Mojave Creek since the grade was completed. The crushed rock used in construction of the railroad grade lies on the surface of the alluvial fan and has not been superposed by additional sediment from the alluvial-fan source. The contour of the vegetation pattern in the floodplain shows that the distal end of the alluvial fan (now cut off) has not been eroded by subsequent floodflows from Mojave Creek.

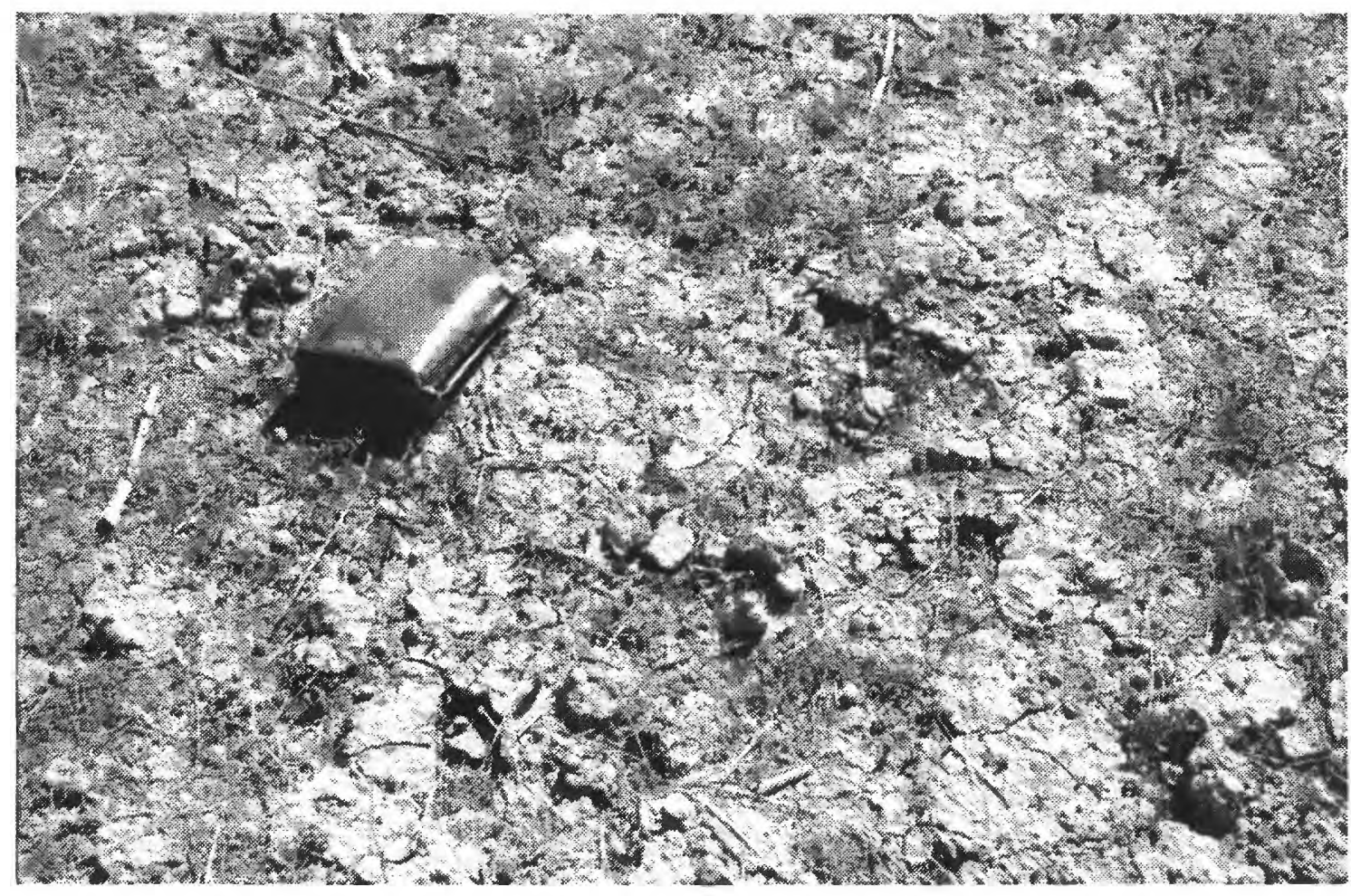

Figure 4. Thin layer of cracked mud on the floodplain surface of Mojave Creek near the Main Base Landfill, Edwards Air Force Base, California. The layer of mud extends north from the distal end of the alluvial fan to the hill bordering the northeast side of the floodplain. 
Any floodflows more than a few inches deep at the distal end of the alluvial fan would have had sufficient force to dislodge and transport the loose sand. To verify this, an experimental value of the critical shear velocity of sand was compared to the force of water on the floodplain expressed as shear velocity, $u_{*}$ :

$$
u_{*}=\sqrt{g d S}
$$

where $g$ is gravitational acceleration, $d$ is flow depth, and $S$ is energy slope. For a typical depth of $1 \mathrm{ft}$ and a slope of 0.003 , the shear velocity is $0.31 \mathrm{ft} / \mathrm{s}$, which is five times the critical shear velocity of $0.06 \mathrm{ft} / \mathrm{s}$ for sand with mean diameter of 1 millimeter. Therefore, if the loose sand has remained at the distal end of the alluvial fan long after the railroad grade had cut off replenishment, then discharges on the floodplain have not been large enough to flow over the distal end of the alluvial fan with significant shear velocity.

The lack of erosive features from floods that inundate the floodplain up to the railroad grade is con- sistent with our observations that no features typical of a wide alluvial channel are visible at a distance from the small channels near the Main Base Landfill. For example, the north side of the railroad grade shows no signs of stream erosion, which would be expected from a large flow constrained in the area between the railroad grade and the northern margin of the floodplain.

\section{Hydraulic and Hydrologic Information}

Northwest of the Main Base Landfill, Mojave Creek is a small alluvial channel confined in a constriction between Bissell Hills and the base of a small butte (see "Flow channel at crest-stage gage," fig. 2). This channel follows the north side of the unpaved Mojave Road for a short distance before diminishing and entering the road. Erosive marks near the crest-stage gage indicate a bankfull channel less than $10 \mathrm{ft}$ wide and about $2 \mathrm{ft}$ deep (fig. 6). A reasonable estimate of bankfull discharge in this channel would be $20 \mathrm{ft}^{2} \times 5 \mathrm{ft} / \mathrm{s}$, or about $100 \mathrm{ft}^{3} / \mathrm{s}$. Somewhat larger discharges could

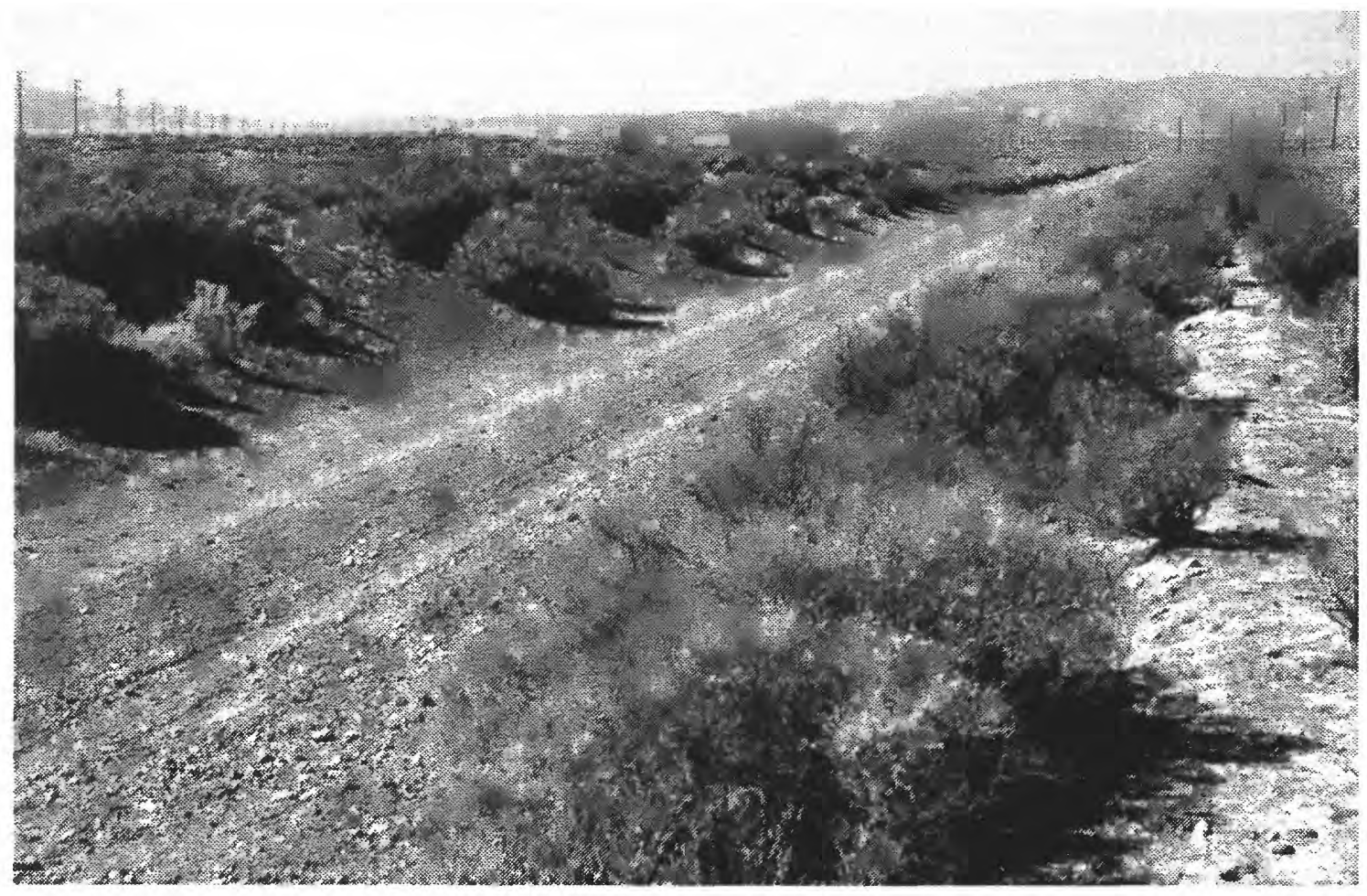

Figure 5. Distal end of an alluvial fan at Mojave Creek near the Main Base Landfill intersected by the railroad grade, Edwards Air Force Base, California. (View to the west) 
overflow this channel without detectable erosion or deposition. However, no flood marks or depositional levees from overbank flows were seen at this location.

A wooden culvert conveys water from south to north under the railroad grade immediately upstream from the flow channel (figs. 2 and 7). The crossing point can be seen in figure 2 where the darkened area ceases its downstream extension south of the railroad grade. The total cross-sectional area of the culvert is about $12 \mathrm{ft}^{2}$. High-water marks indicated ponding between the culvert at the railroad grade and the hill to the southwest. With a water depth of 2 to $3 \mathrm{ft}$ above the culvert opening, the culvert capacity is about 80 to 100 $\mathrm{ft}^{3} / \mathrm{s}$. No erosion by overflow from the pond was found at the top of the railroad grade; all flow in Mojave Creek passes through this culvert.

A smaller wooden culvert (nearly filled with alluvium) crosses under the railroad grade about 1,500 $\mathrm{ft}$ downstream from the larger culvert. No other culverts convey flow from south to north between the smaller culvert and the eastern end of the railroad grade near the Main Base Landfill. Therefore, additional inflow from Bissell Hills to Mojave Creek is negligible along the railroad grade. Although discharges near the Main Base Landfill would be about the same as discharges at the larger culvert and at the crest-stage gage,

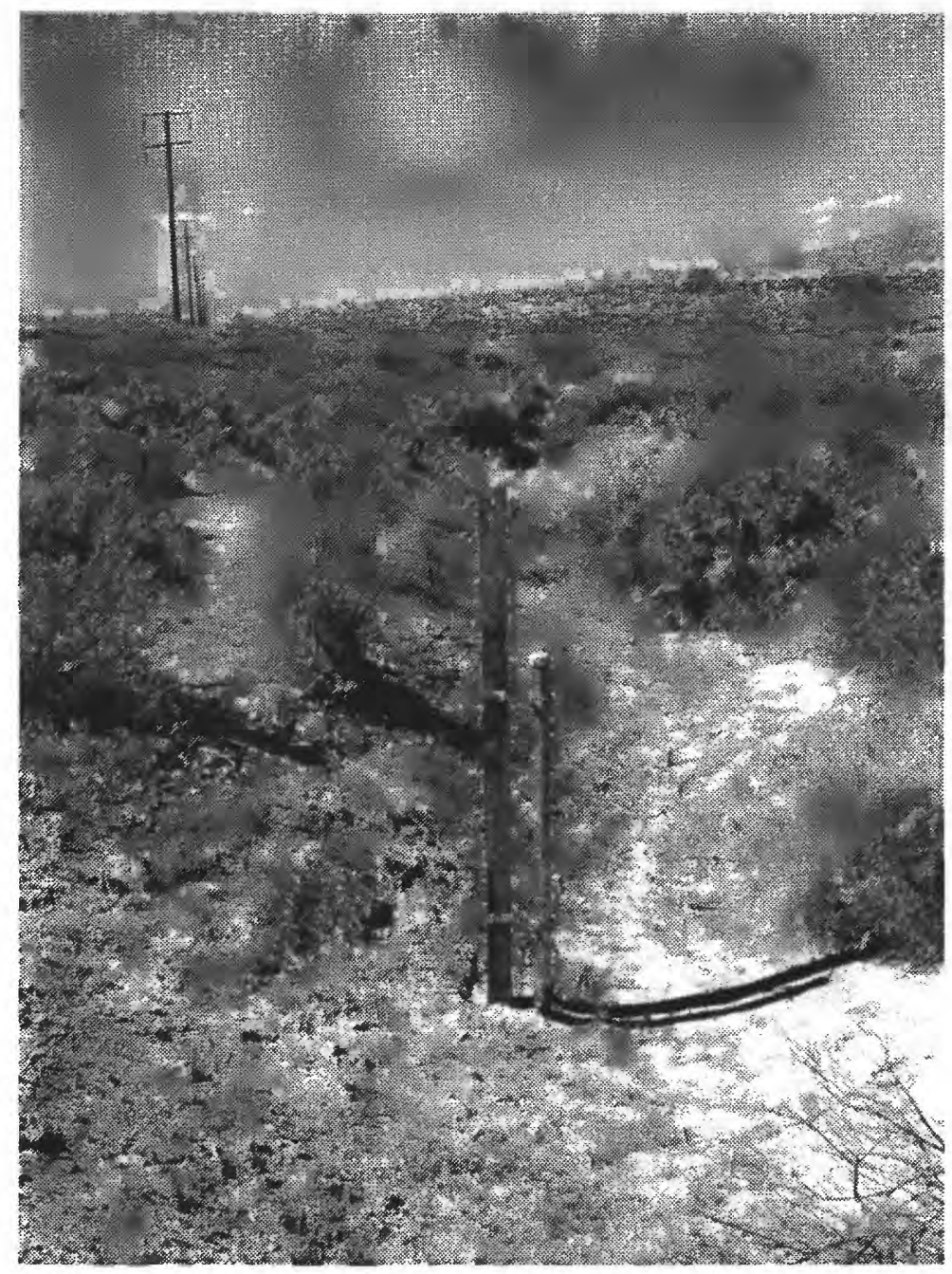

Figure 6. Crest-stage gage in a confined channel of Mojave Creek, Edwards Air Force Base, California. About 1 mile northwest of the Main Base Landfill, Mojave Creek occupies a small alluvial channel in a constriction between Bissell Hills and the base of a small butte. The crest-stage gage is in the foreground. 
the area near the Main Base Landfill was examined for evidence of a larger channel. Erosive features are longlived in a desert environment, commonly remaining visible for decades, and therefore, stream-channel erosion by any large floods in Mojave Creek would likely be preserved. The lack of evidence of a larger channel for Mojave Creek indicates that the visible alluvial channel probably represents the effect of the largest flows during the past few decades or longer.

A similar opinion was expressed by Robert Lichvar (U.S. Army Corps of Engineers, Waterways Experimental Station, oral commun., 1995), who investigated the geomorphological features of Bissell Hills. He stated that the soils in the Mojave Creek watershed are highly permeable (see also Earth Tech- nology, 1993) and that storm runoff immediately infiltrates at the base of the local hills. He also stated that the drainage network was formed during the temperate climate of the late Pleistocene (more than 10,000 years before present) and does not represent the erosive activity of the current dry climate. These factors indicate that the capacity of the visible drainage channels represents the magnitude of discharges to be expected along Mojave Creek. That magnitude may be a few hundred cubic feet per second, as determined by dimensions of the larger culvert beneath the railroad grade, the channel dimensions at the nearby crest-stage gage, and the shallow flow conditions of the floodplain near the Main Base Landfill.

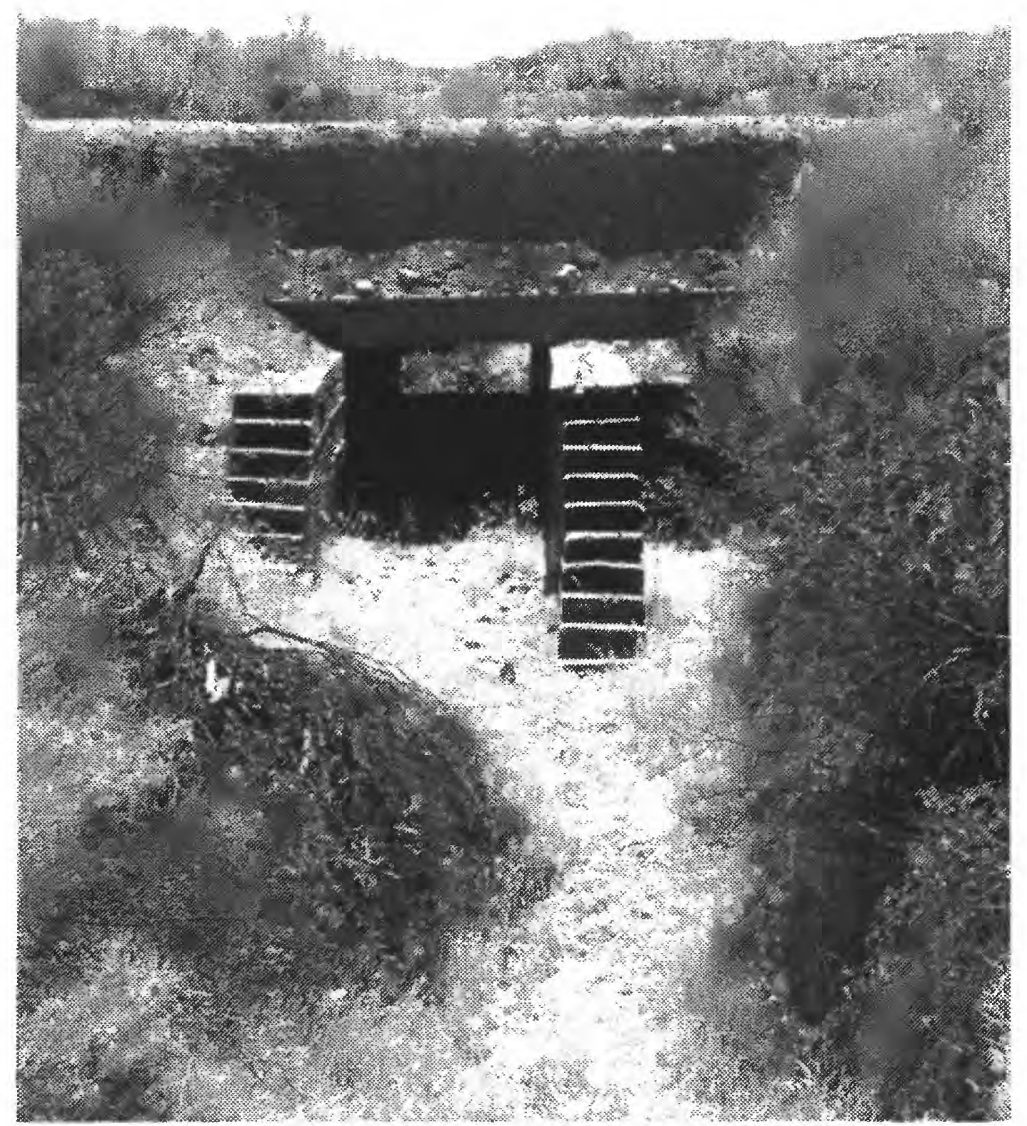

Figure 7. Wooden culvert through which water passes from south to north under the railroad grade immediately upstream from the flow path across the unpaved Mojave Road, Edwards Air Force Base, California. The opening on the right is partly visible; the width of each opening is 3 feet, and the height of each opening is 2 feet. Flow is toward the foreground. 
Local hydrologic information tends to support the conclusion that flood discharges do not inundate the width of the low-lying area near the Main Base Landfill. At Edwards AFB, a total of 3.38 in. of rain fell on March 1, 1983, with a calculated recurrence interval greater than 100 years (Blodgett, 1996). Sedimentary deposits of the flood discharge resulting from this storm were preserved in the arid environment. The farthest extent of the wide, thin layer of cracked mud (fig. 4) probably was left by water that ponded on the floodplain following the 1983 storm, and the high-water marks from ponding above the railroad culvert were probably associated with that same storm.

During March 1995, a few storms over a 14-day period resulted in a rainfall total of $0.88 \mathrm{in}$. at the Main Base. The manager at the landfill stated that storm runoff from the paved area of the disposal site was contained by a culvert outside the weigh station at the landfill and was passed to the floodplain below, where the water ponded. He did not recall any flow in the Mojave Creek floodplain. If average rains in March 1995 did not produce a noticeable flow, then the capacity of the drainage basin for infiltration must be high, as noted by Robert Lichvar (U.S. Army Corps of Engineers, Waterways Experimental Station, oral commun., 1995).

A storm occurred at Edwards AFB on February 20-21, 1996, with total rainfall of $0.90 \mathrm{in}$. for a period of 24 hours. The rainfall total for the 24 -hour period corresponds to an approximate 10-year recurrence interval (Blodgett, 1996). Three crest-stage gage sites on Mojave Creek (maintained by USGS for Edwards AFB) were checked on February 29, 1996. The creststage gage at the upstream corner of Lancaster Boulevard and Rosamond Boulevard showed a flood mark indicating recent flow in the channel. The channel in the culvert on Mojave Creek that passes under Forbes Avenue also showed marks that indicated recent flow. However, the crest-stage gage on the main channel of Mojave Creek, about 0.5 mi upstream from the Main Base Landfill, showed no flood marks from recent flow. During the February 1996 storm, flow in the Mojave Creek was not measurable in the main channel upstream from the Main Base Landfill but was measurable at Forbes Avenue, which is downstream from developed areas of the town of Edwards. This indicates that flow probably infiltrated completely before reaching the landfill, and the flow in the channel at Forbes Avenue resulted from local runoff.

\section{FLOOD DISCHARGES FROM REGIONAL CHARAC- TERISTICS}

Statistical data and analytical procedures were combined in previous studies to derive flood discharges for Mojave Creek without the benefit of local field data or discharge records (GRW Engineers, 1993). The techniques that apply regional characteristics (including drainage area, elevation, and soil properties) in regression equations are well-established and often are necessary to estimate discharge for ungaged streams (Thomas and others, 1994). However, the techniques yielded flood discharges for Mojave Creek above Forbes Avenue that are difficult to reconcile with the direct evidence of flood magnitude in Mojave Creek near the Main Base Landfill.

GRW Engineers (1993), using data curves suggested by the U.S. Corps of Engineers and the County of San Bernadino, developed a semi-analytical method to obtain an estimated 200-year flood discharge for Mojave Creek of 4,000 $\mathrm{ft}^{3} / \mathrm{s}$. An independent calculation by the U.S. Corps of Engineers yielded a 100-year flood discharge at Mojave Creek at Forbes Avenue of $5,350 \mathrm{ft}^{3} / \mathrm{s}$ (GRW Engineers, 1993).

To assess the accuracy and the relative magnitude of these previous estimates, other flood-frequency equations were applied to Mojave Creek for the present study. Regional flood-frequency equations, compiled by Thomas and others (1994) for the Southwestern United States, were applied to Mojave Creek. The equations relate discharges of various recurrence intervals to the drainage area through the form $Q=c A^{b}$, where $A$ is drainage area and the values of $b$ and $c$ were determined by linear regression of values of $Q$ and $A$ for similar watersheds in the southwest (Thomas and others, 1994).

Use of the regional flood-frequency equation for the Southern Great Basin Region 10 (Thomas and others, 1994) was recommended by Robert Meyer (U.S. Geological Survey, written commun., 1996). The recommended least-squares regression equation from Thomas and others (1994), $\mathrm{Q}=850 \mathrm{~A}^{0.69}$, gives a 100 year flood discharge $Q$ of $30,800 \mathrm{ft}^{3} / \mathrm{s}$ for the drainage area $A$ of $182 \mathrm{mi}^{2}$. This equation was developed from data for watersheds with intermittent streams and visible floodplains. Using the regression equation for more arid conditions of south-central Utah, $Q=264 \mathrm{~A}^{0.344}$, the 100-year flood discharge $\mathrm{Q}$ becomes $1,580 \mathrm{ft}^{3} / \mathrm{s}$ for the same drainage area $A$.

Each of these regression equations results in a discharge estimate of thousands of cubic feet per sec- 
ond. Peak discharges determined from direct evidence near the Main Base Landfill are in the hundreds of cubic feet per second. Although regression values for discharge and drainage area probably include a few watersheds similar to Mojave Creek, the generalized regression equation may not provide a 100-year flood discharge representative of Mojave Creek.

\section{WATER-SURFACE PROFILES IN FLOODPLAIN NEAR MAIN BASE LANDFILL}

Flood boundaries for Mojave Creek above Forbes Avenue were determined by GRW Engineers (1993). They routed an estimated flood discharge through cross sections of Mojave Creek using a program to compute water-surface profiles by the standard step method (Henderson, 1966), also known as the step-backwater method. The boundaries were established using hydraulic calculations from cross sections in the reach upstream and downstream from the Main Base Landfill. The cross sections shown by GRW Engineers (1993) were several thousand feet apart and did not include the topography at the landfill. The published flood maps showed the disposal site outside the flood boundaries.

For the USGS study, four cross sections (figs. 8 and 9) were surveyed on the floodplain for Mojave Creek southwest of the Main Base Landfill on January 12,1996 . The cross sections between Mojave Boulevard, the access road, and the borrow area were surveyed on January 30, 1996. Surveyed features included the railroad grade, which rises above the floodplain by $2 \mathrm{ft}$; the center line of the unpaved Mojave Road; and the chain-link fence that intersects the floodplain below the culvert draining the asphalt pavement at the Main Base Landfill.

Cross-section locations were selected by judging the likely flow path between the Main Base Landfill and the unpaved Mojave Road. The floodplain adjacent to the Main Base Landfill had been cleared of vegetation by heavy equipment sometime prior to the survey. At the northwest side of the cleared area, the small channels that cross the floodplain are intersected by the chain-link fence that surrounds the Main Base Landfill. The channels then turn south toward the access road that connects to Mojave Boulevard (fig. 2).

If the water surface in Mojave Creek were to approach the artificial grade on the southwestern side of the disposal site, the railroad grade and the artificial grade below the disposal site would control the flow width as depth increased. The flow width between the railroad grade and the Main Base Landfill boundary decreases downvalley toward the access road. Near the borrow area, the railroad grade merges with the surrounding land surface and ceases to control the flow width. Flow would continue through the open area south of Mojave Boulevard toward Forbes Avenue.

Although physical evidence was found for flood discharges of a few hundred cubic feet per second in the floodplain, a discharge that is an order of magnitude greater was used to test whether larger flows would reach the disposal site. A hypothetical discharge of $2,000 \mathrm{ft}^{3} / \mathrm{s}$ was applied through the standard-step method for flow profiles using the surveyed cross sections of the floodplain adjacent to the Main Base Landfill. A hypothetical discharge of $2,000 \mathrm{ft}^{3} / \mathrm{s}$ was chosen because its magnitude was identified by the regression equation for arid watersheds (Thomas and others, 1994) as the 100-year flood discharge for the given drainage area. Cross-sectional geometry and location were determined from the cross-sectional surveys. Water-surface elevations for the hypothetical discharge were calculated by the standard-step program WSPRO (Water Surface PROfile). The calculated water-surface elevations are lower than the asphalt pavement inside the Main Base Landfill. Some results from the WSPRO computation for $2,000 \mathrm{ft}^{3} / \mathrm{s}$ are given in table 1 .

Table 1. Water-surface elevations computed using standard-step method for Mojave Creek near the Main Base Landfill, Edwards Air Force Base, California

\begin{tabular}{ccccc}
\hline $\begin{array}{c}\text { Cross-section } \\
\text { number }\end{array}$ & $\begin{array}{c}\text { Water-surface } \\
\text { elevation, } \\
\text { in feet }\end{array}$ & $\begin{array}{c}\text { Right bank elevation } \\
\text { at end of section, } \\
\text { in feet }\end{array}$ & $\begin{array}{c}\text { Left bank elevation } \\
\text { at end of section, } \\
\text { in feet }\end{array}$ & $\begin{array}{c}\text { Disposal site } \\
\text { ground elevation, } \\
\text { in feet }\end{array}$ \\
\hline 1 & $2,381.5$ & $2,382.2$ & $2,385.6$ & $2,390.0$ \\
2 & $2,380.7$ & $2,380.6$ & $2,388.4$ & $2,390.0$ \\
3 & $2,379.8$ & $2,380.0$ & $2,384.1$ & $2,390.0$ \\
4 & $2,379.4$ & $2,380.0$ & $2,380.4$ & $2,390.0$ \\
\hline
\end{tabular}




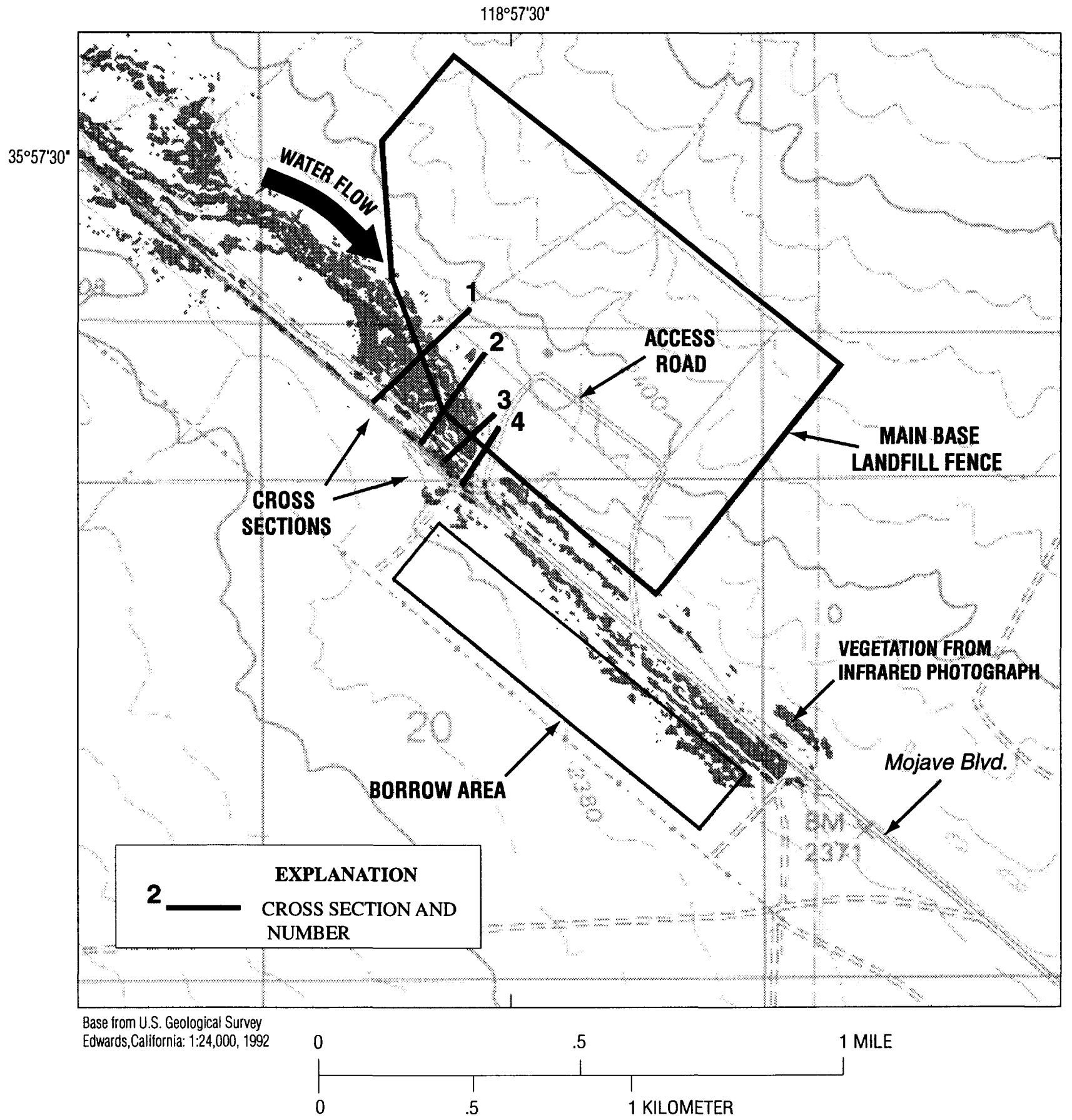

Figure 8. Floodplain of Mojave Creek near the Main Base Landfill boundary, Edwards Air Force Base, California. Cross-section locations for the water-surface profile are shown.The gray areas along Mojave Creek, indicating vegetation on wetted soils, are derived from an infrared aerial photograph taken in 1984. 

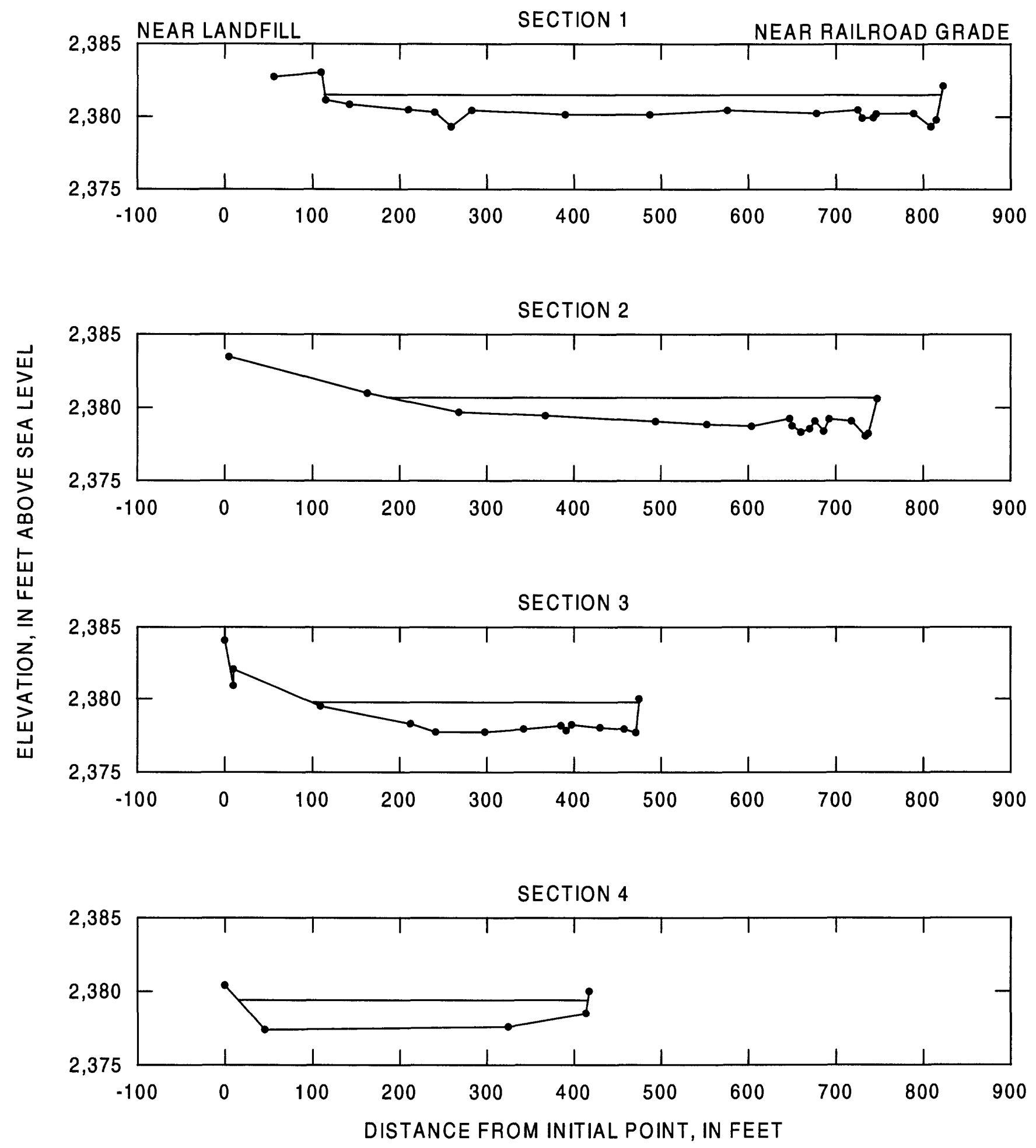

Figure 9. Elevation plots of cross sections of the floodplain for the water-surface profile (numbered in downstream order), Edwards Air Force Base, California. The initial points at left are near the artificial grade around the Main Base Landfill. Cross sections extend to the railroad grade, shown by points at right. Horizontal line on cross sections are water-surface elevations from table 1. (Manning's $n=0.035$; watersurface slope $=0.0024$ ) 
The water-surface elevations for the hypothetical discharge would be very near or at the top of the railroad grade. However, at the railroad grade across from the Main Base Landfill, the railroad-grade edge shows no signs of stream erosion that would be expected from a flood of this magnitude inundating the floodplain. Therefore, the hypothetical discharge of $2,000 \mathrm{ft}^{3} / \mathrm{s}$ must be greater than flood discharges that have occurred in Mojave Creek near the Main Base Landfill since the completion of the railroad grade.

A flood discharge identified as the largest in 100 years does not equate with a flood discharge having a 100 -year recurrence interval. The 100 -year designation means that the discharge has a probability of 0.01 of being exceeded in 100 years. The probability $p$ is the inverse of the recurrence interval $T_{r}$ :

$$
p=\frac{1}{T_{r}}
$$

from

$$
T_{r}=\frac{n+1}{m}
$$

where $n$ is the number of years of record and $m$ is the rank of the annual peak discharge. Although Mojave Creek has no discharge record, a hypothetical distribution of annual peak discharges is associated with any watershed. As the number of years in the population of annual peak discharges increases, the likelihood also increases that a flood discharge has occurred with an exceedance probability $p$ equal to or less than 0.01 . The probability $J$ that a peak annual discharge with a return period of $T_{r}$ years will occur in a period of $n$ years is

$$
J=1-\left(1-\frac{1}{T_{r}}\right)^{n}
$$

For a period of 112 years between the completion of the railroad grade and this investigation of Mojave Creek near the landfill, the probability $J$ of the occurrence of a 100 -year flood is 0.68 . Assuming that the effects of flood erosion are well preserved, there is a $\mathbf{0 . 3 2}$ probability that sedimentological evidence for flood magnitude in the floodplain near the landfill does not include the effects of a 100-year flood discharge.

\section{SUMMARY}

Because the desert environment preserves erosive features for decades, the lack of erosive features along the floodplain margins near the Main Base Landfill indicates that flood discharges greater than a few hundred cubic feet per second have not occurred in the last hundred years. For this reason, reported flood discharges derived from regional characteristics in the range of 1,580 to $5,350 \mathrm{ft}^{3} / \mathrm{s}$ cannot be reconciled with the physical evidence for the magnitude of flooding. The sedimentological evidence at this site also could not be reconciled with published estimates of 100-year flood discharges. The Mojave Creek floodplain does not show signs of flood discharges in that range since the completion of the railroad grade in 1884 .

In the area adjacent to alluvial-fan deposition that is over a hundred years old, flow depths have not been sufficient to dislodge the sediment deposited there before the railroad grade was built. Discharges of a few hundred cubic feet per second may have occurred, as estimated from the dimensions of the railroad culvert and alluvial channel west of the Main Base Landfill. Given the uncertainty in a 100-year flood discharge for this ephemeral stream, a flood discharge as great as any in the last hundred years in Mojave Creek could inundate the access road from Mojave Boulevard but not the disposal site within the Main Base Landfill boundary.

\section{REFERENCES CITED}

Blodgett, J.C., 1996, Precipitation depth-duration and frequency characteristics for Antelope Valley, Mojave Desert, California: U.S. Geological Survey WaterResources Investigations Report 95-4056, 33 p.

Dutcher, L.C., and Worts, G.F., Jr., 1963, Geology, hydrology, and water supply of Edwards Air Force Base, Kern County, California: U.S. Geological Survey Open-File Report (unnumbered), 223 p.

Earth Technology, 1993, Report of disposal site information, main base sanitary landfill, Edwards Air Force Base, California: vols. I-II, $81 \mathrm{p}$. and appendices.

GRW Engineers, 1993, Edwards Air Force Base IRP Flood Study: 23 p. and 4 appendices.

Henderson, F.M., 1966, Open Channel Flow: New York, MacMillan, $522 \mathrm{p}$.

Thomas, B.E., Hjalmarson, H.W., and Waltemeyer, S.D., 1994, Methods for estimating magnitude and frequency of floods in the southwestern United States: U.S. Geological Survey Open-File Report 93-419, 211 p. 